\title{
Ferrimycobactin Reductase Activity from Mycobacterium smegmatis
}

\author{
By KEVIN A. MCCREADY AND COLIN RATLEDGE \\ Department of Biochemistry, University of Hull, Hull HU6 $7 R X$
}

(Received 15 November 1978; revised 2 January 1979)

\begin{abstract}
Ferrimycobactin reductase activity from Mycobacterium smegmatis grown under irondeficient conditions had a $K_{\mathrm{m}}$ for ferrimycobactin of less than $4 \mu \mathrm{M}$ and a $K_{\mathrm{m}}$ for NADH of $1.75 \mathrm{~mm}$. Salicylate $(0.12 \mathrm{mM})$, which is synthesized by this bacterium, could substitute for EDTA as an acceptor of $\mathrm{Fe}^{2+}$ in the assay system. Reagents which react with thiol groups $\left(\mathrm{HgCl}_{2}, N\right.$-ethylmaleimide) at $0.1 \mathrm{~mm}$ inhibited activity by about $40 \%$; other inhibitors ( $\mathrm{KCN}, \mathrm{NaN}_{3}$, carbonyl cyanide $m$-chlorophenylhydrazone and 2,4-dinitrophenol) were less effective (though these inhibited active iron transport, which uses exochelin and not mycobactin; Stephenson \& Ratledge, 1979). The rate of ferrimycobactin reduction in extracts was about ten times faster than the rate observed in vivo following a shift-up of low-iron cells to high-iron status. Reduction of iron in ferri-ferrioxamine B, ferriexochelin MS and ferric ammonium citrate occurred at comparable rates to ferrimycobactin reduction.

Ferrimycobactin reductase activity was undiminished in $M$. smegmatis grown under ironsufficient conditions. A similar activity was found in extracts of Escherichia coli and Candida utilis where it still required NADH. Yeast alcohol dehydrogenase reduced ferrimycobactin independently of NADH; this activity was attributed to the free thiol groups of this protein. Reductase activity therefore may be associated with a protein whose principal function need not be that of a siderophore reductase.
\end{abstract}

\section{INTRODUCTION}

The uptake of iron from various siderophores into microbial cells is becoming increasingly well-documented (Braun, 1978; Ernst et al., 1978) though with little information about how iron is released from these chelates. Ernst \& Winkelmann (1977) and Brown \& Ratledge (1974) reported the occurrence of reductases in Neurospora crassa and Mycobacterium smegmatis which can reduce the iron in, respectively, coprogen and mycobactin, the natural siderophores of these species. Ferrous iron can then be transferred to other molecules within the cell as its affinity for the chelators is low. In Escherichia coli and Fusarium roseum, hydrolysis of the ferric chelate is needed before the iron can be released (Greenwood \& Luke, 1978; Emery, 1976).

The finding by Dailey \& Lascelles (1977) of an 'iron reductase' activity in Spirillum itersonii (using ferric citrate as the iron source) is relevant to an understanding of how iron may be released from its carrier. They suggested that this activity could be associated with one or more sites on the respiratory chain. Lascelles \& Burke (1978) extended this work to Staphylococcus aureus and found that iron reductase activity in membrane preparations was associated with L-lactate dehydrogenase, glycerol-3-phosphate dehydrogenase and nitrate reductase activities using L-lactate and glycerol 3-phosphate as reductants. They concluded that reduced components preceding cytochrome $b$ in the electron transport chain served as sources of reductant for ferric iron. The success of the iron reductase depended, however, on using ferric citrate; when ferri-ferrichrome and ferri-ferrioxamine 
B (Desferal) were used with crude extracts from this organism, as well as from Spirillum itersonii, Rhodopseudomonas spheroides, E. coli and Paracoccus (Micrococcus) denitrificans, there was little or no reduction (Dailey \& Lascelles, 1977). Thus the problem of iron release from the natural siderophore is still unresolved in these organisms as there is no evidence to suggest that uptake of iron is via formation of ferric citrate which is an easily reducible complex.

In this paper, we report our continuing studies on this problem in mycobacteria and suggest that ferrimycobactin reductase activity may be generally distributed rather than being the property of a specific enzyme found only in mycobacteria.

\section{METHODS}

Abbreviations. DNP, 2,4-Dinitrophenol; CCCP, carbonyl cyanide $m$-chlorophenylhydrazone; NEM, $N$-ethylmaleimide.

Organisms, growth and preparation of extracts. Mycobacterium smegmatis NCIB 8548 was grown in shakeflask culture $\left(250 \mathrm{ml}\right.$ Erlenmeyer flasks) in iron-deficient $\left(0.05 \mu \mathrm{g} \mathrm{Fe} \mathrm{ml}^{-1}\right)$ or iron-sufficient $\left(2 \cdot 0 \mu \mathrm{g} \mathrm{Fe} \mathrm{ml}^{-1}\right)$ medium $(100 \mathrm{ml})$ as previously described (Ratledge \& Hall, 1971). Three d-old cells, harvested by filtering through Whatman GF/C glass-fibre filters, were suspended in an equal volume of $0.1 \mathrm{M}$-Tris/ $\mathrm{HCl}$ buffer (pH 7.0) at $2^{\circ} \mathrm{C}$ and disrupted by passage through a chilled French press at $35 \mathrm{MPa}$. The exuded material was incubated with DNAase (Sigma) for $30 \mathrm{~min}$ at $2^{\circ} \mathrm{C}$. After centrifuging at $30000 \mathrm{~g}$ for $30 \mathrm{~min}$ at $2{ }^{\circ} \mathrm{C}$, the supernatant was made to $2 \%(\mathrm{w} / \mathrm{v})$ with respect to streptomycin sulphate and re-centrifuged as before.

Escherichia coli $\mathrm{K} 12$ and Candida utilis were grown under iron-sufficient conditions and extracts were prepared from them in the same manner as for $M$. smegmatis.

Enzyme assay. Ferrimycobactin reductase activity was assayed under anaerobic conditions by Method 2 of Brown \& Ratledge (1974) using $400 \mathrm{nmol}$ ferrimycobactin, instead of $680 \mathrm{nmol}$, with NADH as electron donor. Extracts contained approx. $7 \mathrm{mg}$ protein $\mathrm{ml}^{-1}$.

Recovery of ferrimycobactin from growing cultures exposed to a shift-up of iron. To a $60 \mathrm{~h}$ iron-deficient culture of $M$. smegmatis [about $3 \mathrm{mg}$ dry wt $\mathrm{ml}^{-1}$, containing naturally approx. $1 \%$ (w/v) mycobactin] was added $2.0 \mu \mathrm{g} \mathrm{Fe} \mathrm{ml}^{-1}$ (as $\mathrm{FeSO}_{4} .7 \mathrm{H}_{2} \mathrm{O}$ ) (see McCready \& Ratledge, 1978). The amount of ferrimycobactin which had been produced was determined by ultrasonically disrupting the harvested cells (using one flask per determination) suspended in 0.1 M-EDTA; ferrimycobactin, together with desferrimycobactin, was then extracted into ethanol and the absorbance was read immediately at $450 \mathrm{~nm}$ to give the concentration of the ferric chelate only. The extraction and all other manipulations were performed in iron-free glassware (see Ratledge \& Hall, 1971) to ensure no acquisition of extraneous iron into the mycobactin. The proportion of the added iron which was bound to mycobactin could then be calculated. The total amount of mycobactin was determined by converting the remaining desferrimycobactin to ferrimycobactin in the manner of White \& Snow (1968) and again reading the absorbance at $450 \mathrm{~nm}$.

Materials. Ferrimycobactin S was prepared to an $A_{450}^{1 \%}$ of $44 \cdot 3$ by the method described by Ratledge \& Snow (1974) with final chromatography through Sephadex LH 20. Ferrioxamine B (Desferal; CIBA Laboratories) was converted to the ferric form by adding a stoicheiometric amount of $\mathrm{FeSO}_{4} .7 \mathrm{H}_{2} \mathrm{O}$ (chelated iron is quickly oxidized into the ferric state). Ferriexochelin MS was fraction 3A purified as described by Macham et al. (1977) from M. smegmatis and was donated by Dr M. C. Stephenson. Alcohol dehydrogenase was purified to homogeneity from bakers' yeast by Dr F. M. Dickinson and had a specific activity of about 350 units (mg protein) ${ }^{-1}$.

\section{RESULTS}

Various attempts were made to purify ferrimycobactin reductase activity using conventional procedures. Ammonium sulphate precipitation (precipitate from 20 to $40 \%$ saturation) gave a twofold improvement in specific activity but over $60 \%$ of the total activity was lost. Gel filtration through Sepharose 6B destroyed all activity. Though crude extracts treated with streptomycin sulphate were only about $15 \%$ more active than the original, they were markedly less turbid than the crude extracts and consequently gave more consistent assays. Such preparations were used throughout this work. 
Table 1. Effect of inhibitors on ferrimycobactin reductase activity in extracts of M. smegmatis grown under iron-deficient conditions

$\begin{array}{lcc}\text { Inhibitor } & \begin{array}{c}\text { Concn } \\ (\mathrm{mM})\end{array} & \begin{array}{c}\text { Inhibition of } \\ \text { ferrimycobactin } \\ \text { reductase* } \\ (\%)\end{array} \\ \mathrm{KCN} & 1 & 11 \\ & 10 & 74 \\ \mathrm{NaN}_{3} \dagger & 5 & 13 \\ \mathrm{CCCP} \dagger & 30 & 31 \\ & 0.01 & 0 \\ \mathrm{DNP} & 0 \cdot 10 & 17 \\ \mathrm{NEM} & 2 \cdot 0 & 30 \\ \mathrm{HgCl}_{2} & 0 \cdot 1 & 39 \\ & 0 \cdot 1 & 45\end{array}$

* Enzyme activity in absence of any inhibitor was $0.2 \mathrm{nmol}$ ferrimycobactin reduced $\mathrm{min}^{-1}\left(\mathrm{mg}^{-1} \text { protein }\right)^{-1}$.

$\dagger$ Controls contained the appropriate concentrations of methanol, in which the inhibitors were dissolved.

\section{General properties of the reductase activity}

The activity of the reductase depended on the presence of NADH and EDTA and the maintenance of anaerobicity during the assay. The $K_{\mathrm{m}}$ for NADH was determined over the range 0.167 to $3.33 \mathrm{~mm}$ holding ferrimycobactin constant at $133 \mu \mathrm{M}$. From a double reciprocal plot, the $K_{\mathrm{m}}$ was calculated to be $1.75 \mathrm{mM}$ with a $V_{\max }$ of $3.33 \mathrm{nmol}$ ferrimycobactin reduced $\min ^{-1}(\mathrm{mg} \text { protein })^{-1}$. The $K_{\mathrm{m}}$ for ferrimycobactin was not measurable as the rate of reaction was still maximal at $8.3 \mu \mathrm{M}$-ferrimycobactin, the lowest concentration of substrate which could be accurately determined spectrophotometrically. The $K_{\mathrm{m}}$ therefore cannot be greater than $4 \mu \mathrm{M}$.

The equilibrium constant for the reaction:

$$
\text { Ferrimycobactin }+\mathrm{e}^{-}+\mathrm{H}^{+} \rightleftharpoons \text { Ferromycobactin }
$$

was calculated using the Nernst equation to be $5 \cdot 5 \times 10^{-5}$, assuming an $E_{0}^{\prime}$ value (at $\mathrm{pH} 7$ ) for ferrimycobactin of $-0.265 \mathrm{~V}$ which was calculated by comparing reduction voltages in a differential cathode-ray polarograph (see Ratledge \& Marshall, 1972) with other ironcontaining compounds of known $E_{0}^{\prime}$ values (K. A. McCready, unpublished work). This equilibrium constant is greatly in favour of the oxidized state, but for the reaction:

$$
\text { Ferrimycobactin }+\mathrm{NADH} \rightleftharpoons \text { Ferromycobactin }+\mathrm{NAD}^{+}
$$

a value of 8.2 was obtained which is weakly in favour of the reduced state.

The strong electronegativity of the $\mathrm{Fe}$ (III)/Fe(II) mycobactin system precludes many compounds from acting as reductant if in low concentration. NAD $+/ \mathrm{NADH}$ with its $E_{0}^{\prime}$ of $-0.320 \mathrm{~V}$ (Loach, 1970) can function in this capacity. However, although the acetoacetate $/ \beta$-hydroxybutyrate system has an even lower $E_{0}^{\prime}$ of $-0.346 \mathrm{~V}$ (Loach, 1970), $\beta$-hydroxybutyrate (at 3.3 or $33 \mathrm{~mm}$ ) failed to reduce ferrimycobactin under the usual conditions of assay.

Of the various potential inhibitors of reductase activity (Table 1), $\mathrm{NEM}$ and $\mathrm{HgCl}_{2}$, which react with thiol groups, were by far the most potent. The other inhibitors, $\mathrm{KCN}$, CCCP, $\mathrm{NaN}_{3}$ and DNP, were not as effective as $\mathrm{NEM}$ and $\mathrm{HgCl}_{2}$, although all strongly inhibit iron transport from ferriexochelin into $M$. smegmatis, a process which is not mediated by mycobactin (Stephenson \& Ratledge, 1979). Similar sensitivity of the ferrimycobactin reductase to $p$-chloromercuribenzoate and iodoacetate (each giving $75 \%$ inhibition at $1 \mathrm{~mm}$ ), which are also inhibitors of thiol group activity, had been noted previously (Brown \& Ratledge, 1974).

Salicylic acid $(0 \cdot 12 \mathrm{~mm})$ could replace EDTA in the assay without loss of activity. This 


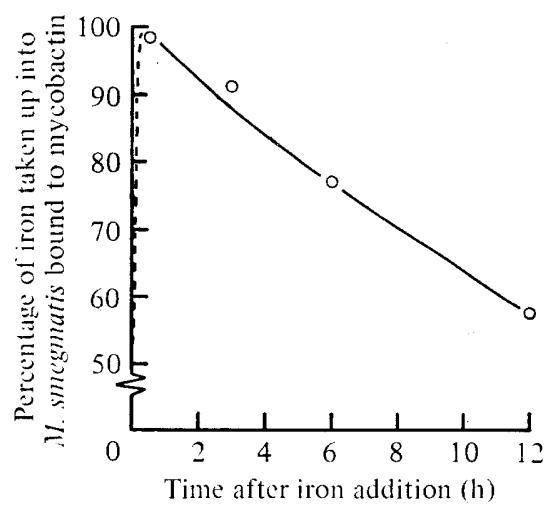

Fig. 1. Loss of iron from ferrimycobactin following addition of $20 \mu \mathrm{g} \mathrm{Fe}^{2+} \mathrm{ml}^{-1}$ to a $60 \mathrm{~h}$ irondeficient culture of $M$. smegmatis. At the time when iron was added, cells contained approx. $10 \mathrm{mg}$ desferrimycobactin ( $\mathrm{g}$ dry $\mathrm{wt})^{-1}$; within 2 min following the iron addition, the cells had turned a light red due to formation of ferrimycobactin. One complete culture flask ( $100 \mathrm{ml}$ medium) was taken for each determination.

may be significant as salicylate is produced by mycobacteria though no firmly established role for it has yet been found (Ratledge et al., 1974).

There was no evidence for hydrolysis of mycobactin by the extracts; recoveries of mycobactin by chloroform extraction after enzymic reduction were about $90 \%$ and were the same as when the substance was recovered following chemical reduction with dithionite in the presence of bovine serum albumin under anaerobic conditions.

Although the observed activity of ferrimycobactin reductase was low, it nevertheless exceeded a value calculated for the release of iron from ferrimycobactin in vivo. When a growing culture of $M$. smegmatis was shifted up from iron-deficient growth to iron sufficiency (see Methods) the additional iron was complexed immediately by the mycobactin, probably being completely taken up within 2 to 3 min and causing the cells to turn light red. (The rate of complexing of iron with mycobactin is evidently much faster than the rate of iron precipitation in the medium. It is not known, however, whether the added $\mathrm{Fe}^{2+}$ is oxidized before or after its chelation to mycobactin.) The iron was slowly released from the ferrimycobactin into the cells over the next $12 \mathrm{~h}$ at a linear rate of about $0.02 \mathrm{nmol} \mathrm{Fe} \mathrm{min}^{-1}$ $(\mathrm{mg} \text { cell dry } \mathrm{wt})^{-1}$ (Fig. 1). This rate was approximately ten times slower than the rate measured in extracts but, of course, was taking place in the second half of the growth phase when the rate of iron acquisition may have been decelerating.

\section{Evidence for the non-specificity of ferrimycobactin reductase activity}

Activity of ferrimycobactin reductase was similar in extracts of $M$. smegmatis grown either iron-sufficiently or iron-deficiently (Table 2). This was somewhat surprising as the concentration of mycobactin in iron-sufficient cells is about 2000 times less than in irondeficient cells (Ratledge \& Marshall, 1972). Reductase activity was also found in crude extracts of organisms not synthesizing mycobactins. Extracts of Escherichia coli and Candida utilis (both grown under iron-sufficient conditions) reduced ferrimycobactin at rates comparable to those found in $M$. smegmatis (Table 2). The activity in each extract resembled that from $M$. smegmatis in being dependent on NADH and being inhibited by 50 to $60 \%$ after pre-incubation with $10 \mu$ M-iodoacetamide.

Since the reductase activity was sensitive to reagents that attack thiol groups (see above and Table 1) and was apparently non-specific in nature, and since thiol reagents [dithiothreitol ( $3.3 \mathrm{mM})$, mercaptoethanol $(33.3 \mathrm{mM})$ and cysteine $(33.3 \mathrm{mM})$ ] reduced ferrimycobactin under anaerobic conditions in the absence of any enzyme and co-factor, alcohol dehydro- 
Table 2. Ferrimycobactin reductase activities in extracts of $M$. smegmatis and other micro-organisms and of yeast alcohol dehydrogenase

About $10 \mathrm{mg}$ protein of each microbial extract was added to the assay mixture $(3 \mathrm{ml})$; for yeast alcohol dehydrogenase, $3.3 \mathrm{mg}$ was added. Ferrimycobactin reductase activities are expressed as $\mathrm{nmol}$ ferrimycobactin reduced $\min ^{-1}$ (mg protein $)^{-1}$.

\begin{tabular}{lc}
\multicolumn{1}{c}{ Source of activity } & Condition of culture \\
$M$. smegmatis & Iron-deficient \\
$M$. smegmatis & Iron-sufficient \\
E. coli & Iron-sufficient \\
C. utilis & Iron-sufficient \\
Bakers' yeast alcohol & - \\
dehydrogenase &
\end{tabular}

$\begin{array}{cc}\begin{array}{c}\text { Requirement of } \\ \text { reductase for } \\ \text { NADH }\end{array} & \begin{array}{c}\text { Activity of } \\ \text { ferrimycobactin } \\ \text { reductase }\end{array} \\ \text { Yes } & 0.12 \\ \text { Yes } & 0 \cdot 13 \\ \text { Yes } & 0 \cdot 21 \\ \text { Yes } & 0.13 \\ \text { No } & 1 \cdot 12\end{array}$

genase [which contains up to 36 thiol groups per molecule (Brändén et al., 1970)] was also tested as a reductant. This protein reduced ferrimycobactin under anaerobic conditions in the absence of NADH (Table 2).

As reductase activity towards ferrimycobactin was seen in several unrelated microorganisms, we investigated whether extracts of $M$. smegmatis could catalyse the reduction of iron in forms other than ferrimycobactin. Using a modified assay procedure, in which salicylate $(0.12 \mathrm{~mm})$ replaced EDTA to prevent spontaneous removal of iron, ferriferrioxamine B (Desferal), ferriexochelin and ferric ammonium citrate were reduced at the respective rates of $0.34,0.14$ and $0.16 \mathrm{nmol} \mathrm{min}^{-1}(\mathrm{mg} \text { protein })^{-1}$, with ferrimycobactin being reduced by the same extract at $0.38 \mathrm{nmol} \mathrm{min}^{-1}(\mathrm{mg} \text { protein })^{-1}$. NADH and anaerobic conditions were still essential for activity in each case.

\section{DISCUSSION}

The general properties of ferrimycobactin reductase activity for $M$. smegmatis are similar in many respects to those reported for the corresponding reductase from $N$. crassa (Ernst \& Winkelmann, 1977). Both activities are sensitive to reagents which react with thiol groups, have similar pH optima (see Brown \& Ratledge, 1974) and can reduce iron chelates other than their own 'natural' substrate. Both reduce ferri-ferrioxamine B at similar rates. The important differences between the two enzymes appear to be: (i) the mycobacterial enzyme has a much lower $K_{\mathrm{m}}$ (less than $4 \mu \mathrm{M}$ ) for its substrate than the enzyme from $N$. crassa $\left(K_{\mathrm{m}}\right.$ for coprogen, $100 \mu \mathrm{M}$ ) though both have similar $V_{\max }$ values, and (ii) the mycobacterial enzyme is not decreased in activity in iron-sufficient cells whereas the fungal enzyme is only $30 \%$ as active after growth under iron sufficiency compared with growth under iron deficiency.

An important finding in the current work was that ferrimycobactin reductase activity is present in micro-organisms other than mycobacteria, which perhaps implies that the activity is associated with a ubiquitous protein or proteins whose principal function need not, therefore, be that of a siderophore reductase. Although reductase activity could also be manifested by yeast alcohol dehydrogenase, this is attributed to the free thiol groups of this protein reacting directly with ferrimycobactin since NADH was not required as a co-factor. With extracts from $M$. smegmatis, as well as E. coli and $C$. utilis, NADH was required and thus, unless we suppose the presence of an enzyme which uses NADH to generate thiol groups on another protein, we presume that direct reduction of the ferrimycobactin was occurring.

The nature of the reductase protein is unknown. It may be associated with the respiratory chain, paralleling the 'iron reductase' found in other micro-organisms (Dailey \& Lascelles, 1977; Lascelles \& Burke, 1978; see Introduction), but, because of the strong electro- 
negativity of ferrimycobactin, this would have to be at a very early site in the sequence. 'Iron reductase' activity is clearly not synonymous with ferrimycobactin or coprogen reductases as this 'enzyme' cannot reduce several naturally occurring siderophores including ferri-ferrioxamine B (see Introduction).

A non-specific protein having a somewhat high $K_{\mathrm{m}}$ for NADH as co-substrate may help to explain the slow rate at which iron is released from mycobactin both in extracts and in vivo (Fig. 1). Mycobactin does not participate in the active uptake of iron in $M$. smegmatis (Stephenson \& Ratledge, 1979) - indeed, the results from studies with inhibitors show that the reductase plays no part in the uptake of iron via exochelin - but it might function as a store of iron if iron in any quantity suddenly became available to the organism (e.g. Fig. 1). The controlled release of this stored iron into the cytoplasm, as and when acceptor molecules are synthesized, is therefore necessary and, as these current experiments show, occurs at a slow rate. It remains an open question as to how the activity of the reductase, whatever its nature, is controlled to regulate the release of iron.

K. A. McCready was supported by a research studentship from The Wellcome Trust. We thank Dr F. M. Dickinson of this department for his gift of yeast alcohol dehydrogenase.

\section{REFERENCES}

BRÄNDÉN, C. I., JöRnVAll, H., EkLUUND, H. \& Furugren, B. (1970). Alcohol dehydrogenases. In The Enzymes, 3rd edn, vol. 11, part A, pp. 103-190. Edited by P. D. Boyer. New York, San Francisco \& London: Academic Press.

BraUN, V. (1978). Structure-function relationships of the Gram-negative bacterial cell envelope. Symposia of the Society for General Microbiology 28, 111-138.

Brown, K. A. \& Ratledge, C. (1974). Iron transport in Mycobacterium smegmatis: ferrimycobactin reductase $[\mathrm{NAD}(\mathrm{P}) \mathrm{H}$ :ferrimycobactin oxidoreductase], the enzyme releasing iron from its carrier. FEBS Letters 53, 262-266.

Dailey, H. A. \& Lascelles, J. (1977). Reduction of iron and synthesis of protoheme by Spirillum itersonii and other organisms. Journal of Bacteriology 129, 815-820.

EMERY, T. (1976). Fungal ornithine esterases: relationship to iron transport. Biochemistry 15, 2723-2728.

ERnst, J. F. \& WinkelmanN, G. (1977). Enzymatic release of iron from sideramines in fungi: NADH: sideramine oxidoreductase in Neurospora crassa. Biochimica et biophysica acta 500, 27-41.

ERnst, J. F., BennetT, R. L. \& Rothfield, L. I. (1978). Constitutive expression of the ironenterochelin and ferrichrome uptake systems in a mutant strain of Salmonella typhimurium. Journal of Bacteriology 135, 928-934.

Greenwood, K. B. T. \& LUKe, R. K. J. (1978). Enzymatic hydrolysis of enterochelin and its iron complex in Escherichia coli. Biochimica et biophysica acta 525, 209-218.

LASCELLES, J. \& BURKE, K. A. (1978). Reduction of ferric iron by L-lactate and DL-glycerol-3phosphate in membrane preparations from Staphylococcus aureus and interactions with the nitrate reductase. Journal of Bacteriology 134, 585-589.

LOACH, P. A. (1970). Oxidation-reduction potentials, absorbance bands and molar absorbance of compounds used in biochemical studies. In Handbook of Biochemistry, Selected Data for Molecular Biology, 2nd edn, pp. J33-J40. Edited by H. A. Sober. Cleveland, Ohio, U.S.A.: The Chemical Rubber Co.

Macham, L. P., Stephenson, M. C. \& Ratledge, C. (1977). Iron transport in Mycobacterium smegmatis: the isolation, purification and function of exochelin MS. Journal of General Microbiology 101, 41-49.

McCready, K. A. \& Ratledge, C. (1978). Amounts of iron, haem and related compounds in $\mathrm{Myco}$ bacterium smegmatis grown in various concentrations of iron. Biochemical Society Transactions $6,421-423$.

Ratledge, C. \& HALl, M. J. (1971). Influence of metal ions on the formation of mycobactin and salicylic acid in Mycobacterium smegmatis grown in static culture. Journal of Bacteriology 108, 312-319.

RatledGe, C. \& Marshall, B. J. (1972). Iron transport in Mycobacterium smegmatis: the role of mycobactin. Biochimica et biophysica acta 279 , 58-74.

Ratledge, C. \& Snow, G. A. (1974). Isolation and structure of nocobactin NA, a lipid-soluble ironbinding compound from Nocardia asteroides. Biochemical Journal 139, 407-413.

Ratledge, C., Macham, L. P., Brown, K. A. \& MARSHALL, B. J. (1974). Iron transport in $M y c o-$ bacterium smegmatis: a restricted role for salicylic acid in the extracellular environment. Biochimica et biophysica acta 372, 39-51.

Stephenson, M. C. \& Ratledge, C. (1979). Iron transport in Mycobacterium smegmatis: uptake of iron from ferriexochelin. Journal of General Microbiology 110, 193-202.

White, A. J. \& SNow, G. A. (1968). Methods for the separation and identification of mycobactins from various species of mycobacteria. Biochemical Journal 108, 593-597. 